\title{
Was the kouprey a feral hybrid? A response to Galbreath et al. (2006)
}

\author{
S. Hedges ${ }^{1}$, C. P. Groves ${ }^{2}$, J. W. Duckworth ${ }^{1}$, E. Meijaard ${ }^{2,3}$, R. J. Timmins ${ }^{4}$ \& J. A. Burton ${ }^{5}$ \\ 1 Wildlife Conservation Society - Asia Program, Wildlife Conservation Society, Bronx, NY, USA \\ 2 School of Archaeology \& Anthropology, Australian National University, Canberra, Australia \\ 3 The Nature Conservancy, Kalimantan Timur, Indonesia \\ 4 Willard Avenue, Madison, WI, USA \\ 5 Veterinary Biomedical Sciences, Royal (Dick) School of Veterinary Studies, University of Edinburgh, Summerhall, Edinburgh, Scotland, UK
}

\section{Correspondence}

S. Hedges, Wildlife Conservation Society - Asia Program, Wildlife Conservation Society, 2300 Southern Boulevard, Bronx, NY 10460, USA.

Email: shedges@wcs.org

doi:10.1111/j.1469-7998.2006.00293.x

In a recent paper, Galbreath, Mordacq \& Weiler (2006) argue that the kouprey Bos sauveli - currently considered to be a valid if possibly extinct species of wild cattle - is or was most likely a feral hybrid form with banteng Bos javanicus and zebu Bos indicus ancestry.

Here, we examine that conclusion and argue that it is premature and thus unhelpful, from the conservation point of view at least, to suggest that the kouprey is a feral hybrid, which would downgrade its status from that of a critically endangered (albeit possibly extinct) animal of high conservation importance (Hedges \& Duckworth, 2000) to an entity of questionable conservation significance. While these genetic results are extremely interesting and warrant swift follow-up with further samples and analyses, there is a danger, if taken on their own, of the premature dismissal of the kouprey from conservation considerations.

The kouprey did not come to the attention of Western science until the 1930s and it was not until 1937 that a specimen (a young male) became available for scientific study. The first formal description was that of Urbain (1937), who named it Bos (Bibos) sauveli. This animal was subsequently designated as the holotype (Urbain, 1939), and is the single specimen of kouprey included in the analysis of Galbreath et al. In 1940, Coolidge published a description of an adult male specimen, which had been shot in Cambodia in March 1939 and was subsequently added to the collection of the Museum of Comparative Zoology at Harvard in the United States. Interestingly, given the present debate, Coolidge was of the opinion that the kouprey was sufficiently distinct to warrant the creation of a new genus, which he called Novibos. The validity of Novibos has, however, been challenged and most subsequent taxonomists have placed kouprey in the genus Bos (Bohlken, 1961).

The kouprey has always been enigmatic and the theory that it may have had a hybrid origin advanced by Galbreath et al. is not new (as they acknowledge). Edmond-Blanc
(1947) suggested that it was a hybrid between banteng and (1) gaur Bos gaurus, (2) water buffalo Bubalus arnee or (3) domestic oxen. Gray (1972) reported that crosses between buffalo Bubalus and members of the genus Bos have invariably proved unsuccessful, whereas crosses between species within Bos are easily obtained. However, the hypothesis that the kouprey is a hybrid receives little or no support from either comparative anatomy or field observations of the behaviour of kouprey (Coolidge, 1940; Wharton, 1957; Lekagul \& McNeely, 1977). Bohlken (1958) revived the hybrid hypothesis; he specifically proposed that kouprey were hybrids between banteng and domestic cattle (zebu). Later, however, Bohlken, (1961), he revised his opinion, recognizing it as a valid species and assigning it to the subgenus Bibos.

\section{On hybridization}

Before discussing the arguments of Galbreath et al., we must be clear about what could be meant by the kouprey being 'a hybrid'. There are three different meanings of 'being a hybrid', and the kouprey must conform, if it is indeed a hybrid, to one of these:

(1) It may be a first-generation cross between two species. Kouprey appear to be homogeneous: they have a certain predictable appearance and size range, and they change colour predictably over their lifespans. They do not possess the variability in morphology expected of F2 hybrids or backcrosses; in each generation, therefore, there must be new crossing between the parent species in order to produce a new set of kouprey. Moreover, given that interspecific hybrids commonly vary according to which species is the sire and which the dam, the homogeneity of kouprey would seem to require that they are always the product of, say, male banteng mating with female zebu. 
(2) The population that is of hybrid origin may be the result of initial hybridization, followed by repeated one-way backcrossing. For this to occur, we have to have two species coexisting, one of them dominant to the other. Males of the dominant species approach herds of the other species where they drive off the males and mate with the females. Each generation this occurs regularly; in each generation, the proportion of genes of the maternal species halves, so that in rather few generations the repeatedly backcrossed hybrids are to all intents and purposes indistinguishable phenotypically from the paternal species, and of course possess its $Y$ chromosome DNA, while still carrying the mitochondrial DNA (mtDNA) of the maternal species. In this way, we have what in effect is one species with the mtDNA of another species. A well-studied example of this is a population of mule deer Odocoileus hemionus in Texas, which bears the mtDNA of white-tailed deer Odocoileus virginianus; Cathey, Bickham \& Patton, 1998).

(3) It may be a species of hybrid origin. Such species are known; indeed, within the Bovini, we have the example of the wisent or European bison Bos bonasus (Verkaar et al., 2004). Verkaar et al. (2004) proposed initial matings between a male proto-bison with a herd of female protoaurochsen, followed by repeated backcrossing of the hybrids with the male parent species as in hybrid model two above; an alternative might be where populations of the two species have become isolated from others of their species, and after the first generation of one-way crossing there is panmixis. In the first case (that proposed by Verkaar et al.), little or no nuclear DNA (nDNA) of the maternal parent species will be detectable in the species that is of hybrid origin; in the alternative case, there will be roughly equal amounts of nDNA descended from both parent species.

None of this is new; indeed, we have understated the complexity of hybridization (Barton, 2001; Hewitt, 2001; Bell \& Travis, 2005). This complexity requires an appropriately comprehensive methodological and analytical approach if one wishes to make strong inferences about the history of taxa - an approach we shall show is lacking in the study of kouprey reported by Galbreath et al. (2006). In an influential review, Ballard \& Whitlock (2004) argue that mtDNA is not a sufficient marker for phylogeographic studies if the focus of the investigation is the species and not the organelle. They state, '[it] is difficult to gather an unbiased dataset about the relative impact introgression has on phylogenies from mtDNA in contrast to nDNA' and go on to say, in taxa with some level of hybridization or migration, there is a non-negligible probability of introgression of mtDNA from one taxon into another. This can happen just by chance (because of the low effective size of mtDNA), by selective pressure (because of local adaptation of the mitochondria) or by selective introgression following mutational meltdown in small populations. In each case, the mtDNA is equally or more sensitive to introgression than nDNA, and this introgression can occur despite the levels of gene flow or hybridization between the populations being very low. Moreover, the introgression of mtDNA can reflect chance events, either in the form of genetic drift or the variance of selection. As a result, the rest of the genome may tell a very different story, and the results from mtDNA may not reflect the typical history of the taxa involved'.

\section{Critique of Galbreath et al.}

Galbreath et al. do not present any genetic evidence for kouprey having zebu ancestry. Indeed, they note that, '[the] available kouprey haplotype is quite different, and phylogenetically far removed, from both zebu and Bos taurus (humpless domestic ox) haplotypes (Hassanin \& Ropiquet, 2004)'. Their argument for zebu ancestry apparently relies on Bohlken's morphometric analyses, which was presumed to demonstrate that 'the kouprey was suspiciously intermediate between banteng ... and domestic zebu'. Bohlken in fact, as noted above, subsequently changed his mind about the origin of kouprey, recognizing it as a valid species and assigning it to the subgenus Bibos. No subsequent published study of kouprey morphology has suggested a zebu ancestry (Hassanin \& Ropiquet, 2004).

We further suggest that, in the light of our earlier discussion on the nature of hybridization, Galbreath et al. are overly reliant on mtDNA sequences and that additional analyses involving Y chromosome DNA and multiple nuclear markers are needed before strong conclusions can be drawn about the origin of kouprey. It is essential to include multiple molecules with distinct evolutionary histories if one wants to make strong inferences about the history of taxa (Ballard \& Whitlock, 2004).

So what do the results of Galbreath et al. tell us? They show a close relationship between the mtDNA sequences of a single kouprey (the holotype) and two probably Cambodian banteng, and both banteng sequences showed the unique derived transversion pair that Hassanin \& Ropiquet (2004) considered potentially diagnostic for the kouprey. Galbreath et al. conclude from this that most likely 'the kouprey was not a natural species, but rather a self-perpetuating feral form with banteng and zebu (and conceivably B. taurus) ancestry' (we shall call this hypothesis one, H1). As we demonstrated above, this conclusion does not in fact follow from the data; not only were no $\mathrm{Y}$ chromosome DNA or other nDNA examined, but several explanations are possible for their findings concerning mtDNA, and they do not specify precisely what form of mixed ancestry (hybridization) they have in mind. Presumably, they are implying our meaning (3) of hybridization, above.

Galbreath et al. do, however, acknowledge two alternative hypotheses to explain their results (we shall call these $\mathrm{H} 2$ and $\mathrm{H} 3$ ), and these are much more specific about the actual nature of hybridization:

H2: 'The kouprey could have originated hundreds of thousands of years ago via massive genetic introgression involving a banteng population and a zebu-like wild ox population'. This would seem to differ from their favoured hypothesis $\mathrm{H} 1$ only in that the zebu-like ancestor is envisaged as a wild species (perhaps Bos namadicus, the presumed ancestor of the zebu) and in the timing of the hybridization event. 
H3: Kouprey are/were a true species but '[as they] became progressively rarer in recent years, there could have been modest introgression of kouprey mtDNA into banteng population(s). If so, [Galbreath et al's two] banteng specimens could conceivably possess mtDNA that originated with kouprey females'. Note, however, that it would not be necessary to suppose that this integration is a recent phenomenon; it does not depend on the increasing rarity of the kouprey. It is in fact a special case of our meaning (2) of hybridization, above.

We suggest that there is a fourth hypothesis:

H4: Kouprey are/were a true species and there was some level of interbreeding between kouprey and banteng in the past, so remnant banteng mtDNA is present in some kouprey (including the holotype studied by Hassanin \& Ropiquet (2004) and by Galbreath et al.) as a result of incomplete lineage sorting.

Furthermore, animals are only considered to be 'feral' if they or their ancestors were formerly domestic but they subsequently live(d) independently of humans. The term 'feral hybrid' only therefore applies to $\mathrm{H} 1$ and arguably only then if the putative banteng ancestors were domestic animals; if $\mathrm{H} 2, \mathrm{H} 3$ or $\mathrm{H} 4$ reflect the true origin of kouprey then use of the term 'feral' would be incorrect.

Hypothesis number two $(\mathrm{H} 2)$ suffers the same flaw as the hypothesis favoured by Galbreath et al. (H1), that is it merely assumes that kouprey have a zebu ancestry, which has nowhere been shown to be the case, relying instead entirely on the original hypothesis of Bohlken (1958), which he himself later repudiated (Bohlken, 1961). We think H3 is the most likely explanation. We prefer it over our own $\mathrm{H} 4$, because the mtDNA in question is almost equally different from gaur and (Javan) banteng, implying that it is indeed that of a third distinct species, rather than that of Cambodian banteng, which, in morphology, are barely distinguishable from Javan banteng (E. Meijaard, P. Grubb, \& C. P. Groves, pers. obs.).

\section{Conclusion}

On the basis of the data and analyses presented by Galbreath et al., it is premature to decide that any (let alone all) kouprey were hybrids, feral or otherwise. Further analyses of banteng and kouprey specimens are needed to decide between the alternative hypotheses discussed above. Large numbers of kouprey trophies (skulls or partial skulls with horns) exist in private collections in Thailand and every effort should be made to obtain samples from these specimens. Zebu specimens should also be included in the analyses. Both nuclear and mitochondrial markers, including Y-chromosome DNA, should be used and the issues of sample size and the problem of finding the pure-bred banteng needed for meaningful comparisons across the species' range will also need to be addressed. We would also like to emphasize the need to have independently verifiable nongenetic-based identifications for all specimens included in the analyses because there are multiple cases of serious erroneous genetic conclusions being reached through mis- identification of source individuals, as shown by Ruedas et al. (2000). Furthermore, zoo animals should not be used for these analyses as the origin of zoo specimens, particularly in south-east Asia, will in most cases be open to doubt as animal traders often fail to keep adequate records of the source of their specimens, specimens are misidentified/ labelled and hybridization is a known issue especially among the Bovidae (e.g. Namikawa \& Widodo, 1978; Davis \& Read, 1985; Burton, Hedges \& Mustari, 2005). The last of these problems was highlighted, in a study of particular relevance to the present case, when 'Bali cattle'-like animals that appeared phenotypically to be banteng were found to have haemoglobin profiles that revealed a genetic history similar to known hybrid cattle specimens (Namikawa \& Widodo, 1978; Davis \& Read, 1985).

Galbreath et al. suggest that banteng from outside the range of the kouprey should be sampled in order to test hypothesis three (H3) because that hypothesis unambiguously predicts that banteng from outside the kouprey's range will not possess mtDNA phylogenetically related to that of the kouprey. They suggested south-west Cambodia as a suitable site but we argue that the uncertainties surrounding the original range of the kouprey require specimens of wild banteng from further afield than south-western Cambodia and from known localities to be used for the additional tests; specimens from Java should be included as these will be particularly helpful for the test of $\mathrm{H} 3$.

We would also like to suggest that, as a matter of urgency, those domestic cattle breeds that have been variously suggested as being either domestic kouprey, or at least as having some kouprey ancestry, be sought out and carefully studied genetically. These include the Thanh-hoa cattle (Wharton, 1957), the peculiar animal studied by Hassanin et al. (2006) and the various other breeds referred to therein, and the Stieng ox, of which there is a skull in the Paris Museum's Laboratory of Comparative Anatomy, which is a typical kouprey (C. P. Groves, pers. obs.).

Finally, we believe that one of the key messages arising from this debate about the origin of the kouprey should be recognition that the forces that caused the likely extinction of the kouprey are still extant in much of south-east Asia and the challenge is therefore to stop other species such as the banteng suffering the same fate as the kouprey (whatever it is/was).

\section{Acknowledgements}

We thank G. Galbreath, A. Hassanin, J. Walston and $\mathrm{H}$. Weiler for fruitful discussions. We also thank C. Bradshaw and an anonymous reviewer for their helpful comments on an earlier version of this paper.

\section{References}

Ballard, J.W.O. \& Whitlock, M.C. (2004). The incomplete natural history of mitochondria. Mol. Ecol. 13, 729-744. 
Barton, N.H. (2001). The role of hybridization in evolution. Mol. Ecol. 10, 551-568.

Bell, M.A. \& Travis, M.P. (2005). Hybridization, transgressive segregation, genetic covariation, and adaptive radiation. Trends Ecol. Evol. 20, 358-361.

Bohlken, H. (1958). Vergleichende Untersuchungen an Wildrindern (Tribus Bovini Simpson, 1945). Z. Jahrb. Allg. Zool. Physiol. 68, 113-202.

Bohlken, H. (1961). Der Kouprey, Bos (Bibos) sauveli Urbain, 1937. Z. Säugetierk. 26, 193-254.

Burton, J., Hedges, S. \& Mustari, A.H. (2005). The anoas (Bubalus depressicornis \& B. quarlesi): taxonomic status, distribution, and conservation needs. Mammal Rev. 35, 25-50.

Cathey, J.C., Bickham, J.W. \& Patton, J.C. (1998). Introgressive hybridization and nonconcordant evolutionary history of maternal and paternal lineages in North American deer. Evolution 52, 1224-1229.

Coolidge, H.J. (1940). The Indo-Chinese forest ox or Kouprey. Mem. Mus. Compar. Zool. Harvard College 54, 421-531.

Davis, S. \& Read, B. (1985). The status of the North American captive herds of the Banteng, Bos javanicus d'Alton. Zoo Biol. 4, 269-279.

Edmond-Blanc, F. (1947). A contribution to the knowledge of the Cambodian wild ox or kouproh. J. Mammal. 28, 245-248.

Galbreath, G.J., Mordacq, J.C. \& Weiler, F.H. (2006). Genetically solving a zoological mystery: was the kouprey (Bos sauveli) a feral hybrid? J. Zool. (Lond.) 270, 561-564.

Gray, A.P. (1972). Mammalian hybrids: a checklist with bibliography. Technical communication animal breeding and genetics, Edinburgh no. 10 (revised), Commonwealth Agricultural Bureau, Farnham Royal, Bucks, UK.

Hassanin, A. \& Ropiquet, A. (2004). Molecular phylogeny of the tribe Bovini (Bovidae, Bovinae) and the taxonomic status of the Kouprey, Bos sauveli Urbain, 1937. Mol. Phylogenet. Evol. 33, 896-907.

Hassanin, A., Ropiquet, A., Cornette, R., Tranier, M., Pfeffer, P., Candegabe, P. \& Lemaire, M. (2006). Has the kouprey (Bos sauveli Urbain, 1937) been domesticated in Cambodia? Comptes Rendues Biologies 329, 124-135.

Hedges, S. \& Duckworth, J.W. (2000). Bos sauveli. In IUCN 2006. 2006 IUCN Red List of Threatened Species. IUCN 2006: 〈www.iucnredlist.org $\rangle$. Downloaded on 11 October 2006.

Hewitt, G.M. (2001). Speciation, hybrid zones and phylogeography-or seeing genes in space and time. Mol. Ecol. 10, 537-549.

Lekagul, B. \& McNeely, J.A. (1977). Mammals of Thailand. Bangkok, Thailand: Association for the Conservation of Wildlife.

Namikawa, T. \& Widodo, W. (1978). Electrophoretic variation of hemoglobin and serum albumin in the Indonesian cattle including Bali cattle (Bos banteng). Japanese $J$. Zootechn. Sci. 49, 817-827.

Ruedas, L.A., Salazar-Bravo, J., Dragoo, J.W. \& Yates, T.L. (2000). The importance of being earnest: what, if anything, constitutes a "specimen examined?". Mol. Phylogenet. Evol. 17, 129-132.

Urbain, A. (1937). Le Kou-Prey ou Boeuf Sauvage Cambodgien. Bull. Soc. Zool. Fr. 62, 305-307.

Urbain, A. (1939). Note complémentaire sur le Boeuf Sauvage du Cambodge (Bos (Bibos) sauveli Urbain). Bulletin du Muséum 2e s., t. XI, No 6.

Verkaar, E.L.C., Nijman, I.J., Beeke, M., Handkamp, E. \& Lenstra, J.A. (2004). Maternal and paternal lineages in cross-breeding bovine species. Has Wisent a hybrid origin? Mol. Biol. Evol. 21, 1165-1170.

Wharton, C.H. (1957). An ecological study of the Kouprey. Novibos sauveli (Urbain). Monographs of the Institute of Science and Technology, Monograph 5, Manila, Philippines. 